\title{
Disease processes of the parasite Perkinsus marinus in eastern oyster Crassostrea virginica: minimum dose for infection initiation, and interaction of temperature, salinity and infective cell dose
}

\author{
Fu-Lin E. Chu*, Aswani K. Volety \\ Virginia Institute of Marine Science, School of Marine Science, College of William and Mary, Gloucester Point, \\ Virginia 23062, USA
}

\begin{abstract}
Experiments were conducted to: (1) test the response of oysters to different doses of the oyster parasite Perkinsus marinus and to 2 stages, meronts or prezoosporangia; and (2) investigate the synergistic effects of temperature, salinity and infective cell concentration on $P$. marinus infection in oysters. A dose-dependent response of $P$. marinus infection was found in oysters inoculated with 0,10 , $10^{2}, 10^{4}$, and $10^{5}$ meronts or prezoosporangia per oyster and maintained at 22 to $25^{\circ} \mathrm{C}$ and 14 to $21 \mathrm{ppt}$ for 8 to $12 \mathrm{wk}$. The minimum dose required to infect oysters was $10^{2}$ meronts or prezoosporangia per oyster through shell cavity inoculation. Interactive effects between temperature, salinity, and infective cell dose on $P$. marinus prevalence was insignificant in the experiment, in which oysters were challenged by $0,2.5 \times 10^{3}$ or $2.5 \times 10^{4}$ meronts per oyster and held at 9 temperature-salinity regimes $(10,15$ and $25^{\circ} \mathrm{C}$ at 3,10 and $20 \mathrm{ppt}$ ). However, there was a significant positive interaction relevant to infection intensity between temperature and salinity, and between temperature and meront dose. Temperature was the most important factor followed, respectively, by the infective cell dose and salinity in determining the susceptibility to $P$. marinus in oysters. Reduced condition index was observed in moderately to heavily infected oysters and in oysters at $25^{\circ} \mathrm{C}$.
\end{abstract}

KEY WORDS: Oyster Crassostrea virginica - Oyster parasite Oyster disease - Perkinsus marinus Temperature Salinity

\section{INTRODUCTION}

The protozoan parasite Perkinsus marinus (Dermo) has caused significant mortality in the eastern oyster Crassostrea virginica from the mid-Atlantic to the Gulf of Mexico in the United States since the 1950s. P. marinus is now more prevalent in mid-Atlantic waters, and Chesapeake Bay in particular, than the other common protozoan pathogen, Haplosporidium nelsoni (MSX) (Andrews 1988, Ragone-Calvo \& Burreson 1995). The meront and prezoosporangia stages of the parasite can cause $P$. marinus infection in oysters (Volety \& Chu 1994). The meront stage is more effective than the prezoosporangia stage in inducing infection (Volety \&

·E-mail: chu@vims.edu
Chu 1994) and is believed to be the principal stage for transmitting disease in the field (Perkins 1988). The distribution and abundance of $P$. marinus in the field are limited by temperature and salinity (see reviews by Andrews 1988, Andrews \& Ray 1988). The dosage of $P$. marinus cells is also considered to be critical in disease transmission (Mackin 1956, 1962). However, thus far no laboratory study has been conducted to examine the interactive effects of these 3 crucial factors on the disease processes in oysters. Similarly, the number of $P$. marinus infective cells that are required to transmit the disease is unclear. In this study, we investigated (1) the response of eastern oysters to different doses of meront and prezoosporangia of P. marinus; (2) the minimal dose for initiation of $P$. marinus infections in eastern oysters; and (3) the interaction between tempera- 
ture, salinity and infective cell dose on $P$. marinus infections in the eastern oysters.

\section{METHODS AND MATERIALS}

Preparation of meront and merozoite suspensions. Meronts and merozoites (immature meronts) of Perkinsus marinus were isolated and purified as follows: oysters heavily infected with $P$. marinus were rinsed thoroughly with filtered $(0.22 \mu \mathrm{m})$ York River water (YRW) and subsequently homogenized in $0.22 \mu \mathrm{m}$ filtered YRW with a blender (Virtis, Model 23) at high speed for $2 \mathrm{~min}$. The tissue suspension was then passed through a series of $100,50,35$ and $20 \mu \mathrm{m}$ meshes to remove oyster tissue residues (La Peyre \& Chu 1994). Meronts contained in the filtrate were further purified by repeated centrifugation and washing. The number of meronts in suspension was counted using a hemacytometer (Reichert, Buffalo, NY, USA) and adjusted to the desired concentrations. About $99 \%$ of the isolated infectives were meront/merozoites and $\leq 1 \%$ were schizont (sporangium)

Preparation of prezoosporangia. Prezoosporangia were isolated and purified from Perkinsus marinus infected oyster tissues previously cultured in fluid thioglycolate medium (FTM) for 4 to $5 \mathrm{~d}$ on the basis of the method described by Chu \& Greene (1989).

Perkinsus marinus diagnosis. P. marinus infections were diagnosed using a thioglycollate tissue assay (Ray 1952, 1966). At the end of each experiment, one piece each of rectal, digestive diverticulum and mantle tissues were removed from individual oysters and incubated in FTM for 4 to $5 \mathrm{~d}$. Disease intensity was ranked $0,1,3,5$ (negative, light, moderate, or heavy) based on the number of prezoosporangia present in the tissues. Weighted prevalence (WP = sum of disease intensity rank/number of oysters examined) was calculated according to Ray (1954), Mackin (1962) and Andrews (1988)

Experiments. Responses of oysters to different doses of meronts and prezoosporangia: Two replicate experiments were performed to test the responses of eastern oysters to different doses of meronts or prezoosporangia using oysters from the Damarsicotta River, Maine, USA, a region beyond the geographical distribution of Perkinsus marinus. The ambient temperature and salinity at the time of collection were $1^{\circ} \mathrm{C}$ and $30 \mathrm{ppt}$ (February 1994) and $20^{\circ} \mathrm{C}$ and $30 \mathrm{ppt}$ (August 1994) in Expts 1 and 2, respectively. The oysters (size range 5.0 to $6.5 \mathrm{~cm}$ ) were gradually acclimated in 1000 I tanks over a period of. $6 \mathrm{wk}$ to the ambient salinity of YRW and room temperatures (Expt 1.

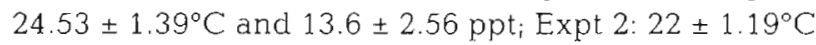
and $20.64 \pm 0.55 \mathrm{ppt}$. Oysters were fed $0.2 \mathrm{~g}$ algal paste (Thalassiosira weissflogii) per individual daily and the water was changed 3 times per week during acclimation. A total of 150 oysters were used for each experiment. Before the experimental oysters were challenged with $P$. marinus, 15 randomly selected oysters were diagnosed for possible $P$. marinus infection using tissue thioglycollate assay. All oysters were diagnosed to be negative at that time. Condition indices $(\mathrm{CI}=$ dry meat weight/dry shell weight $\times 100$; Lucas \& Beninger 1985) of these oysters were also determined. The remaining 135 oysters were divided into 9 groups (15 oysters per group) and were inoculated into the shell cavity with a dose of $0,10,10^{2}, 10^{4}$, or $10^{5}$ freshly isolated meronts/merozoites or prezoosporangia in $100 \mu l$ of $0.22 \mu \mathrm{m}$ filtered YRW per oyster. These oysters were then randomly arranged in individual $2.0 \mathrm{l}$ plastic chambers containing $1 \mu \mathrm{m}$ filtered aerated YRW. Water was changed every other day and the oysters fed as before. Oysters of each group were sampled to measure $P$. marinus prevalence and intensities, and condition index (Cl) after $92 \mathrm{~d}$ (Expt 1) and $60 \mathrm{~d}$ (Expt 2) following $P$. marinus challenge.

Interactive effects of temperature, salinity and infective cell dose: The interactive effects between temperature, salinity and infective cell doses were tested by exposing oysters to 3 different doses $(0,2.5 \times$ $10^{3}$ or $2.5 \times 10^{4}$ ) of freshly isolated meronts/merozoites per oyster) at 9 salinity-temperature combinations: 10,15 and $25^{\circ} \mathrm{C}$ at 3,10 and 20 ppt for $60 \mathrm{~d}$. Five hundred oysters were collected from Damarsicotta River (January 1993; ambient temperature $=0^{\circ} \mathrm{C}$, salinity $=$ $32 \mathrm{ppt}$ ). A random subsample of 30 oysters was examined for Perkinsus marinus infection and condition index. No $P$. marinus infection was detected in any of the 30 oysters. Experimental oysters were gradually acclimated over a period of $67 \mathrm{~d}$ in $1000 \mathrm{l}$ tanks to the 9 test temperature and salinity regimes indicated above using $1.0 \mu \mathrm{m}$ filtered YRW adjusted to desired temperature and salinity. After the oysters were acclimated to their respective test temperatures and salinities, they were randomly placed in individual chambers and maintained thereafter in aerated water of the relevent test salinity and temperature Water was changed every other day and each oyster was fed daily with $0.1 \mathrm{~g}$ algal paste. The shell cavities of individual oysters $(\mathrm{N}=15)$ were inoculated with $100 \mathrm{l}$ filtered YRW containing $0,2.5 \times 10^{3}$ or $2.5 \times 10^{4}$ freshly isolated P. marinus meronts. Mortality was monitored through the experimental period and dead oysters were examined for P. marinus infection.

Statistical analyses. Log linear model and logistic regression (Agresti 1990) were used to determine: (1) the significance of interactive effects among tem. perature, salinity, and Perkinsus marinus infective cell doses on disease prevalence; and (2) differences in 
infection prevalence in oysters challenged by different doses of meronts or prezoosporangia. A log linear model was first used to determine the interactive effects of temperature, salinity and dose of $P$. marinus cells on infection prevalence in oysters. Since no interactive effects were observed among temperature, salinity and $P$. marinus cell dose on infection prevalence, individual effects were analyzed by the more parsimonious model, logistic regression. Analysis of variance was used to determine: (1) effects of $P$. marinus cell stages and cell doses (2-way ANOVA) on oyster $\mathrm{CI}$ in dose response Expts 1 and 2; (2) effects of temperature-salinity-infective cell dose ( 3 -way ANOVA) on $\mathrm{CI}$ in oysters in the interactive effect experiment; (3) difference in CI between infected and uninfected oysters (1-way ANOVA); and (4) interactive effects of temperature-salinity-infective cell dose (3-way ANOVA) on infection intensity. A multiple comparison test (Tukey) was used to evaluate the differences among treatment means.


Fig. 1. Crassostrea virginica. (A) Prevalence and (B) intensity of Perkinsus marinus in oysters $92 \mathrm{~d}$ (Expt 1) after inoculation with $0,10,10^{2}, 10^{4}$, or $10^{5}$ meronts or prezoosporangia $(n=14$ or 15 per group)

\section{RESULTS}

\section{Dose response in oysters}

Infection prevalence and intensity

A dose-dependent response of Perkinsus marinus infection prevalence was observed in the 2 replicate experiments, in oysters exposed to $0,10,10^{2}, 10^{4}$ and $10^{5}$ meronts or prezoosporangia ( $\mathrm{p}<0.0001$; Figs. $1 \mathrm{~A} \&$ $2 \mathrm{~A}$ ). A similar pattern was shown in infection intensity, expressed as weighted prevalence (Figs. 1B \& 2B). The meront stage caused much higher $(p<0.05)$ infection prevalence and intensity in oysters than did prezoosporangia. The infection prevalences in oysters challenged by $10,10^{2}, 10^{4}$, and $10^{5}$ meronts was 0,13 , 50 and $71 \%$, respectively, in Expt 1 and was $0,13,67$, and $80 \%$, respectively, in Expt 2 . Oysters inoculated with prezoosporangia of concentrations corresponding to meront-challenged groups resulted in prevalences
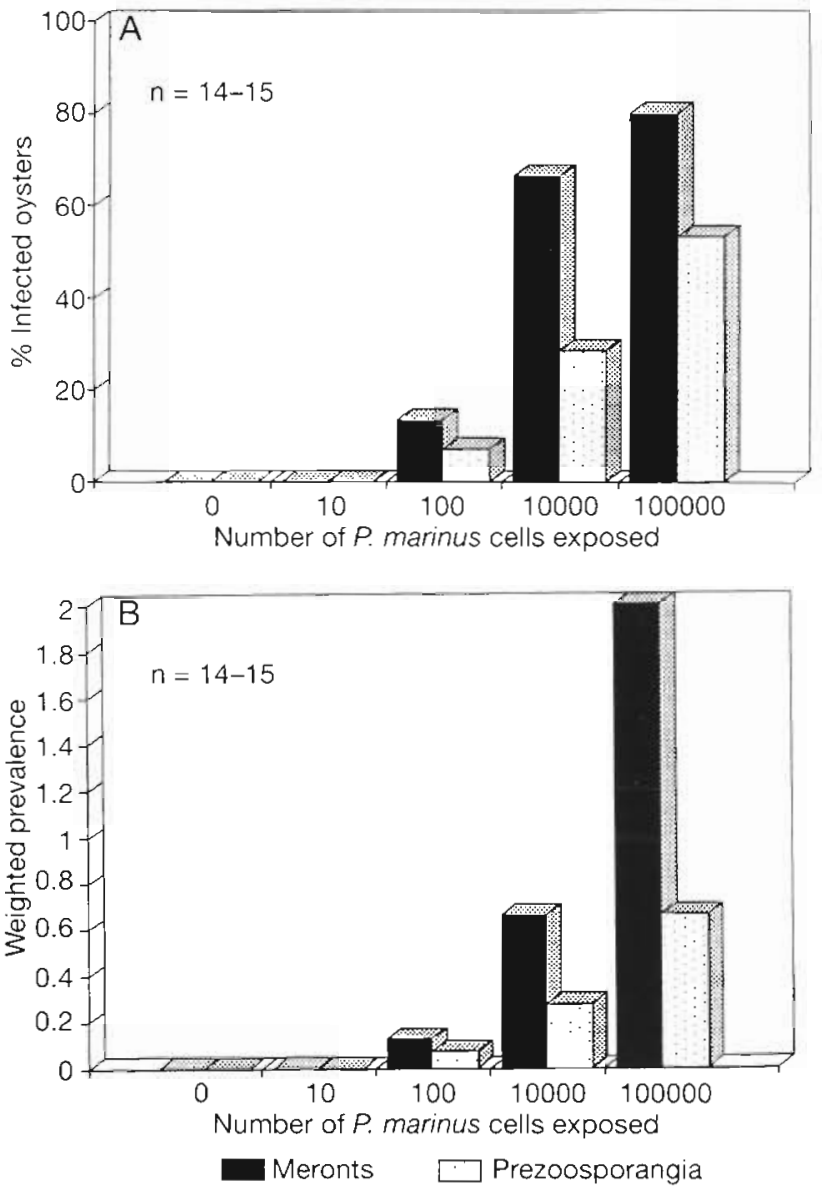

Fig. 2. Crassostrea virginica. (A) Prevalence and (B) intensity of Perkinsus marinus in oysters $60 \mathrm{~d}$ (Expt 2) after inoculation with $0,10,10^{2}, 10^{4}$, or $10^{5}$ meronts or prezoosporangia ( $\mathrm{n}=14$ or 15 per group) 


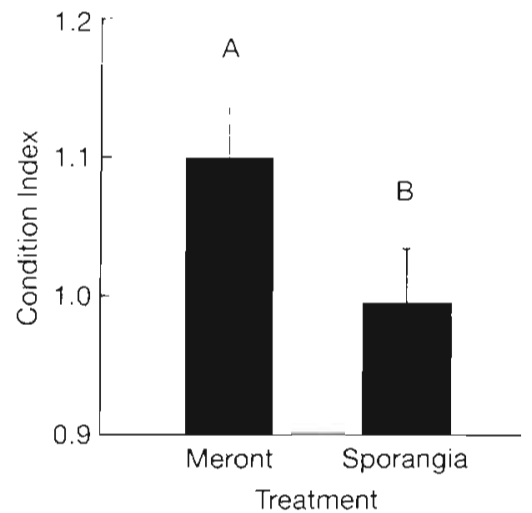

Fig. 3. Crassostrea virginica. Mean $\mathrm{CI}( \pm \mathrm{SE})$ in meront-and prezoosporangia-challenged oysters. Different letters denote significance and difference $(p<0.05)$

of $0,14,20$ and $33 \%$, respectively, in Expt 1 and 0,7,29 and 53\%, respectively in Expt 2. No infections were detected in control oysters. The lowest dose that initiated a detectable $P$. marinus infection was $10^{2}$ meronts or prezoosporangia per oyster. No mortality occurred during the experimental period in either experiment.

\section{Condition index}

In Expt 1, when data were pooled from all dose groups regardless of infection, the $\mathrm{Cl}$ of prezoosporangia-challenged oysters was significantly ( $\mathrm{p}<0.05$ ) lower than meront-challenged oysters (Fig. 3). No significant differences in CI were observed between meront-challenged and prezoosporangia-challenged oysters in Expt 2 ( $p>$ $0.05)$. There was no significant difference in $\mathrm{Cl}$ between infected and uninfected or among dose groups in both experiments.
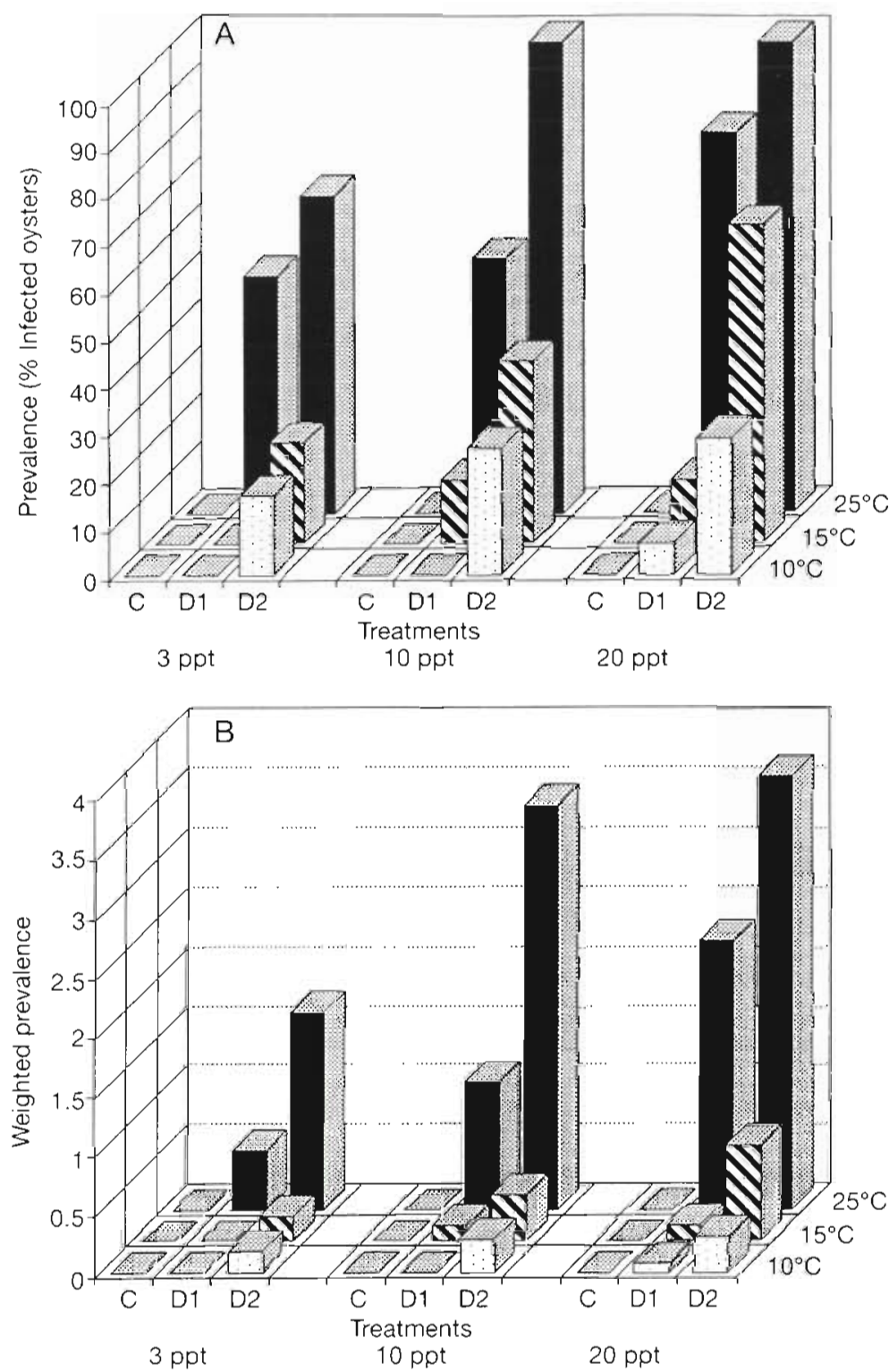

Fig. 4. Crassostrea virginica. (A) Prevalence and (B) intensity of Perkinsus marinus in oysters at different temperature and salinity regimes after being challenged with 2 different doses of $P$. marinus infective cells. $\mathrm{C}$ : control D1: $2.5 \times 10^{3}$ meronts oyster ${ }^{-1}$ : D2: $2.5 \times 10^{4}$ meronts oyster $^{-1}$

\section{Interaction of temperature, salinity and Perkinsus marinus cell doses}

\section{Infection prevalence and intensity}

Increased infection prevalence and intensity (Fig. 4A, B) occurred at high temperatures ( $p<0.0001)$ and salinities $(p<0.0001)$, and there was a dose-dependent response to infective cells $(p<0.0001)$. The results of a log linear model analysis revealed that temperature was the most important factor in determining the sus- ceptibility of oysters to Perkinsus marinus. This was followed, respectively, by the dose of infective particles and salinity. The effect of the 3-way interaction among temperature, salinity and meront doses on disease prevalence was found to be insignificant $(\mathrm{p}>$ 0.05). However, there was a significant and positive 2-way interaction between temperature and salinity $(p<0.0001$ ), and between temperature and meront dose $(p<0.01)$ on infection intensity. Mortalities occurred in oysters during acclimation. Mortality was particularly heavy when the acclimation salinity 
Table 1 Crassostrea virginica. \% Mortality of oysters during the acclimation period. Numbers in parentheses indicate mortality (no. dead/total no.)

\begin{tabular}{|cccc|}
\hline Salinity (ppt) & \multicolumn{3}{c|}{$\begin{array}{c}\text { Temperature }\left({ }^{\circ} \mathrm{C}\right) \\
15^{\circ} \mathrm{C}\end{array}$} \\
& $10^{\circ} \mathrm{C}$ & $25^{\circ} \mathrm{C}$ \\
\hline 3 & $22(10 / 45)$ & $27(12 / 45)$ & $76(34 / 45)$ \\
10 & $2(1 / 45)$ & $4(2 / 45)$ & $0(0 / 45)$ \\
20 & $2(1 / 45)$ & $0(0 / 45)$ & $2(1 / 45)$ \\
\hline
\end{tabular}

and temperature reached $3 \mathrm{ppt}$ and $25^{\circ} \mathrm{C}$ (Table 1). However, none of the dead oysters were found to be infected with $P$. marinus. Since the mortalities occurred before $P$. marinus challenge, the number of dead oysters was not included in disease prevalence calculation.

\section{Condition index}

Oyster CI was reduced significantly ( $p<0.0001)$ with an increase in temperatures (Fig. 5). Neither salinity nor meront concentrations affected $(p>0.05)$ the CI of oysters. When the CI data of infected or uninfected oysters from all treatments were pooled, the CI of the former was significantly lower $(p<0.0001)$ than the latter

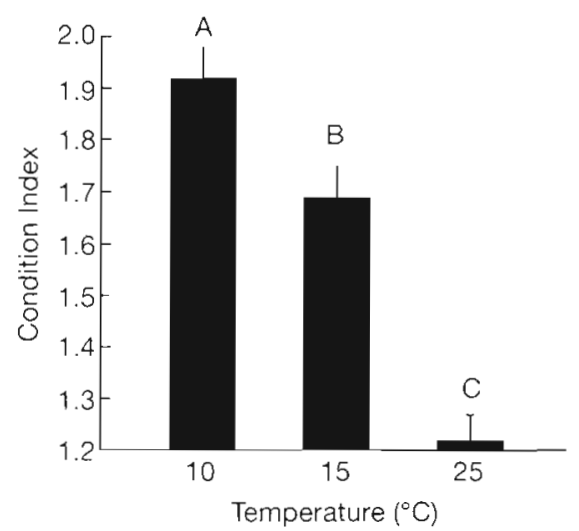

Fig. 5. Crassostrea virginica. Mean condition index $( \pm \mathrm{SE})$ of oysters maintained at 10,15 and $25^{\circ} \mathrm{C}$. Different letters denote significance and differences $(p<0.05)$

\section{DISCUSSION}

The relationship between ambient infective cell concentrations and infection rate, and the number of Perkinsus marinus cells that are required to initiate an infection, is of great interest. In addition to temperature and salinity, $P$. marinus infective cell concentration has been considered to be a crucial factor for dis- ease transmission among oysters in the field (Mackin 1956, 1962). Mackin (1962) argued that the observed low P. marinus prevalence and intensity in areas with high river or fresh water input is a result of dilution of waterborne infective particles. The dose-dependent responses of oysters to $P$. marinus infection demonstrated in the present study shows that on-site concentration of infective cells is indeed important in P. marinus transmission. Dose was the second important factor (after temperature) in contributing to $P$. marinus infections in oysters. The dose response in oysters to in vitro cultured $P$. marinus was studied by Bushek (1994). Similar to our results, he observed increased infection prevalence and intensity in oysters as the dose of $P$. marinus cells increased. An earlier study by Mackin (1962) and Valiulis (1973) also showed that there was a relationship between oyster mortality and inoculated infective cell dose. All of these results support Mackin's view that diluting infective particles during the peak infection season (summer-fall) by influx of fresh water or tidal flushing should decrease the rate of new infections in oyster populations although low salinity is also a controlling factor (Mackin 1962)

As shown by the present study, a minimum number of infective cells is required for induction of Perkinsus marinus infection: i.e. $10^{2}$ meronts or prezoosporangia per oyster via shell cavity inoculation. While no infection was detected in oysters 92 and $60 \mathrm{~d}$ after inoculation with 10 meronts or prezoosporangia in our study, in a previous investigation development of light infection was noted in oysters $105 \mathrm{~d}$ after receiving a dose of 10 cells per oyster injected into their shell cavity (Valiulis 1973). We believe that the dosage required for $P$. marinus transmission probably lies between 10 and $10^{2}$ per oyster by shell cavity injection. Mackin (1962) found that direct shell cavity injection of 1.0 to $5.0 \times 10^{2}$ $P$. marinus cells per oyster is necessary to cause disease-related mortality. P. marinus is probably acquired by filtering the water and may be eliminated through feces and pseudofeces (Bushek et al. 1994). Thus, the number of cells required to effect transmission may be much greater in the field.

How Perkinsus marinus infective cells, discharged from carriers or released from infected gapers, actually enter the host oyster is unclear. Since other alternatives appear to be absent, entry through filtration/ feeding is assumed to be the main route of $P$. maxinus transmission in nature. However, shell cavity injection appeared to be more effective than feeding in infection induction studies (Bushek 1994, Perkins 1994). Thus, although in nature more than 10 to $10^{2} P$. marinus infectives cells may be required to inititate infection in oysters, once this number of infective cells are trapped in the shell cavity during feeding and/or filtration processes, infection will result. 
Consistent with our previous finding (Volety \& Chu 1994), the meront stage caused much higher Perkinsus marinus infection prevalence and intensity in oysters than prezoosporangia. Volety \& Chu (1994) speculated that the higher infectivity/pathogenicity of meronts than prezoosporangia is because of the rapid multiplication of inoculated meronts at warm temperatures (i.e. 21 to $27^{\circ} \mathrm{C}$ ). Exactly what occurs after the prezoosporangia are injected into the oyster shell cavity is unknown. There may be a lag time for the inoculated prezoosporangia to transform to meront stage, or culturing meronts in FTM may affect the infectivity/pathogenicity of the subsequent prezoosporangia. It has been reported that prezoosporangia developed in FTM produced meront/merozoites through bipartition and protoplast clevage (La Peyre 1993).

Perkinsus marinus is most dominant and abundant in subtropical and tropical regions. Temperature has long been documented in field and laboratory studies to be a factor limiting $P$. marinus infection (Mackin 1951, 1956, Ray 1954, Andrews \& Hewatt 1957, Quick \& Mackin 1971, Andrews \& Ray 1988, Chu \& La Peyre 1993a). It is not surprising that among the factors tested, temperature turned out to be the most important. Similarly, Fisher et al. (1992) found temperature to be more influential than salinity on $P$. marinus intensity and mortality in oysters from the Gulf of Mexico, maintained at different test temperatures and salinities. It has also been demonstrated that in vitro warm temperatures (i.e. 21 to $28^{\circ} \mathrm{C}$ ) favor $P$. marinus development (Perkins 1966. Chu \& Greene 1989) and the proliferation rate increased with increasing temperature (Volety 1995). In the Gulf of Mexico region, fluctuations of disease prevalence in oysters were noted to be more sensitive to changes in temperature than to salinity (Mackin in Ray 1954). In the Chesapeake Bay region, the results of analysis of the last $10 \mathrm{yr}$ data indicate that $P$. marinus activity and annual. periodicity is largely correlated with the fluctuations of seasonal temperatures (Burreson \& Ragone-Calvo 1996). However, it should be noted that water along the Gulf coast, unlike Chesapeake Bay, usually stays warm yearround. Between 1986 and 1989, the seasonal shift of $P$. marinus infection was found to be associated with the change of salinity caused by rainfall and river runoff rather than temperature (Powell et al. 1992).

Although under laboratory-controlled conditions salinity is less influential than temperature or Perkinsus marinus cell concentration in controlling $P$. marinus infection in oysters, it has been well documented that susceptibility to infection by $P$ marinus in oysters is significantly and positively correlated with salinity (Chu et al. 1993. Chu \& La Peyre 1993b). Only light infections were observed in oysters below $10 \mathrm{ppt}$ in the present study. In nature, $P$. marinus infection is more abundant and intense in areas of elevated salinity (Scott et al. 1985, Andrews 1988, Andrews \& Ray 1988, Craig et al. 1989, Sonjat \& Gauthier 1989. Crosby \& Roberts 1990, Ragone-Calvo \& Burreson 1.995) In vitro development of the parasite has also been reported to be significantly affected by salinity (Perkins 1966, Chu \& Greene 1989). Salinity lower than 6 ppt inhibited the sporulation of prezoosporangia (Chu \& Greene 1989) Low salinities (<12 ppt) also significantly reduced the viability of in vitro cultured $P$. marinus meronts (Buresson et al. 1994).

To our best knowledge, this is the first laboratory investigation of the potential synergetic effects of temperature-salinity-infective cell dose on Perkinsus marinus infection in oysters. Clearly, temperature and salinity each have a significant and direct effect on the outcome of the interaction between the host and the parasite. Infective cell concentration is certainly another crucial factor for intiation of $P$. marinus infection in oysters. However, the interactive effects of these 3 factors is likely more striking than any single factor acting alone. Although this interactive effect on infection prevalence was statistically insignificant, the positive interaction between temperature and salinity, and between temperature and meront dose, significantly intensified the infection. Based on data collected from field samples, temperature and salinity interaction on $P$. marinus infection intensity was noted in a field study conducted on the Gulf coast (Soniat 1985). A recent study by Ragone-Calvo \& Burreson (1994) also suggests that a combination of low temperature and salinity significantly restricts the $P$. marinus activity in oysters. The decline of $P$. marinus prevalence and intensity during winter appears more rapidly in low salinity areas than in high salinity areas in the Chesapeake Bay (Burreson \& Ragone-Calvo 1996). The synergistic effects of high temperature and high salinity should work in favor of the parasite. Several consecutive years of droughts and warm summers resulted in exceptional high oyster mortality in the Chesapeake Bay caused by P. marinus infection (Andrews 1988) The combined effects of temperature and salinity on in vitro $P$. marinus development were assessed by Perkins (1966) and by Chu \& Greene (1989). High temperature-salinity treatment shortened the time for prezoosporangia developing to sporulation. The positive interaction between temperature and infective cell concentration may also explain why $P$. marinus infection in oysters is greatest in the summer months in midAtlantic water During summer, overwinter infections generally progress towards moderate to heavy infections and high disease-associated mortality usually occurs during the warmest time (late July and August) of the year. At that time, infective cells discharged from live and dead infected oysters in the water col- 
umn should increase significantly. Concentrations of $P$. marinus-like cells resembling the meront stage were reported in the range 3000 to 9000 cells $1^{-1}$ in the upper Chesapeake Bay during the warm months (March to October) between 1992 and 1993 (Dungan \& Roberson 1993). Assuming an average of 6000 cells $l^{-1}$ present in ambient water and an oyster filtration rate of $\geq 81$ water $\mathrm{h}^{-1}$ (Galtsoff 1964) results in an encounter rate $\geq 48000$ cells $\mathrm{h}^{-1}$. Chronic feeding of high levels of $P$. marinus may be necessary to cause infection in oysters in the field (Bushek 1994). Given that the dose required for infection initiation lies between 10 and $10^{2}$ infective cells per oyster by shell cavity inoculation and that an oyster can encounter $\geq 48000$ cells $\mathrm{h}^{-1}$ in the warm months of a year, it is easy to see why infection rate reaches its peak in the summer months: a positive interactive effect of temperature and infective cell concentration. It is not understood though why high concentrations of infective cells were found as early as March and April in the Dungan \& Roberson (1993) study. It is very unlikely that infections acquired in the previous year would develop to moderate or heavy intensity during the spring months and release large amount of $P$. marinus cells. The methodology of employing $P$. marinus polyclonal antibodies to quantify $P$. marinus infective cells has the disadvantage of crossreactivity; thus the reported $P$. marinus concentrations (Dungan \& Roberson 1993) may be substantially overestimated.

The reduced $\mathrm{Cl}$ noted in infected oysters in the temperature-salinity dose experiment is an effect of advanced infection. Most of the infected oysters at higher temperatures, salinities, and dose were moderately to heavily infected (Fig. 4B). In contrast, the intensity of infection in the dose response experiments were light. Reduction of CI was previously reported in oysters heavily infected by Perkinsus marinus (Paynter \& Buresson 1991, Dittman 1993) and MSX (Newell 1985, Barber et al. 1988a, b). In Expt 1, the Cl of prezoosporangia-challenged oysters was significantly lower than meront-challenged oysters and is similar to our previous findings (Volety \& Chu 1994). However, such effect was not seen in Expt 2. It is not known why oysters challenged by prezoosporangia had lower CI than oysters challenged by meronts.

High mortality recorded in oysters at temperatures above $15^{\circ} \mathrm{C}$ and salinity less than 10 ppt during acclimation suggests that $3 \mathrm{ppt}$ and $25^{\circ} \mathrm{C}$ are stressful for oysters adapted to cold and high salinity environment. Overall, the decreased CI in oysters at higher treatment temperature (i.e. 15 and $25^{\circ} \mathrm{C}$ ) may be due to the combined effects of the following: (1) higher metabolism; (2) infection advancement; and (3) stressing coldadapted oysters (Damariscotta River) by high temperature treatments.
In summary, Perkinsus marinus susceptibility and disease progression is positively correlated with temperature, salinity and the number of infective cells the oyster encountered. Although no synergistic effects was demonstrated among the 3 factors, temperature in combination with infective particle or with salinity significantly affect disease progression. Temperature was determined to be the most important factor, followed by infective cell dose and then salinity, in determining the subsequent disease development in oysters. A minimum number of infective cells i.e. between 10 and $10^{2}$ cells per oyster by shell cavity inoculation) was required to induce $P$. marinus infection in oysters. Therefore, culture of oysters in tributaries with high river water input and/or fresh water run off could effectively dilute $P$. marinus infective elements, thus providing some level of protection to oysters from infection. Disease progression and temperature stress caused condition index reduction in the host.

Acknowledgements. This work was supported in part by the Oyster Disease Research Program (grant no. NA16FL040201), National Marine Fisheries Service, NOAA. The authors thank G. Constantin for invaluable technical assistance, Drs R. Hale and K. Webb for critical reviews of the first draft of the manuscript and Dr R. Diaz for his advice in statistical analysis. We are grateful to Dr F. O. Perkins for allowing us to cite his unpublished results and Dr S. Ray and the 2 anonymous reviewers for valuable suggestion and criticisms. VIMS contribution no. 1991

\section{LITERATURE CITED}

Agresti A (1990) Categorical data analysis. John Wiley \& Sons, New York, p 79-129

Andrews JD (1988) Epizootiology of the disease caused by the oyster pathogen Perkinsus marinus and its effects on the oyster industry. Am Fish Soc Spec Publ 18:47-63

Andrews JD, Hewatt WG (1957) Oyster mortality studies in Virginia. II. The fungus disease caused by Dermocystidium marinum in oysters of the Chesapeake Bay. Ecol Monogr 27:1-25

Andrews JD, Ray SM (1988) Management strategies to control disease caused by Perkinsus marinus. Am Fish Soc Spec Publ 18:257-264

Barber BJ, Ford SE, Haskin HH (1988a) Effects of the parasite MSX (Haplosporidium nelsoni) on oyster (Crassostrea virginica) metabolism. I. Condition index and relative fecundity. J Shellfish Res 7:25-31

Barber BJ, Ford SE, Haskin HH (1988b) Effects of the parasite MSX (Haplosporidium nelsoni) on oyster (Crassostrea virginica) metabolism. JI. Tissue biochemical composition. Comp Biochem Physiol 91A:603-608

Burreson EM, Ragone-Calvo LM, La Peyre JF, Counts F, Paynter KT (1994) Acute osmotic tolerance of cultured cells of the oyster pathogen Perkinsus marinus (Apicomplexa: Perkinsida). Comp Biochem Physiol 109A:575-582

Burreson EM, Ragone-Calvo LM (1996) Epizootiology of Perkinsus marinus of oysters in Chesapeake Bay with emphasis on data since 1985. J Shellfish Res 15:17-34

Bushek D (1994) Dermo disease in American oysters: genetics of host-parasite interactions. PhD dissertation, Rutgers, The State University of New Jersey, New Brunswick 
Bushek D, Allen SK, Alcox KA, Gustafson R, Ford SE (1994) Dose response of the eastern oyster, Crassostrea virginica, to cultured cells of Perkinsus marinus, the agent of Dermo disease. $J$ Shellfish Res 13:313

Chu FL, Greene KH (1989) Effect of temperature and salinity on in vitro culture of the oyster pathogen, Perkinsus marinus (Apicomplexa: Perkinsea). J Invertebr Pathol $53: 260-268$

Chu FLE, La Peyre JF (1993a) Perkinsus marinus susceptibility and defense related activities in eastern oysters Crassostrea virginica: temperature effects. Dis Aquat Org 16:223-234

Chu FLE, La Peyre JF (1993b) Development of the disease caused by the parasite, Perkinsus marinus and defenserelated hemolymph factors in three populations of oysters from Chesapeake Bay, USA. J Shellfish Res 12:21-27

Chu FLE, La Peyre JF, Burreson CS (1993) Perkinsus marinus infection and potential defense-related activities in eastern oysters, Crassostrea virginica: salinity effects. J Invert Pathol 62:226-232

Craig A, Powell EN, Fay RR, Brooks JM (1989) Distribution of Perkinsus marinus in Gulf Coast oyster populations. Estuaries 12:82-91

Crosby MP, Roherts CF (1990) Seasonal infection intensity cycle of the parasite Perkinsus marinus (and an absence of Haplosporidium spp.) in oysters from a South Carolina salt marsh. Dis Aquat Org 9:149-155

Dittman DE (1993) The quantitative effects of Perkinsus marinus on reproduction and condition index in the eastern oyster, Crassostrea virginica. J Shellfish Res 12:127

Dungan CF, Roberson BS (1993) Flow cytometric quantification and analysis of Perkinsus marinus cells present in estuarine waters. Final Report, NOAA NMFS Oyster Disease Research Program, Award no. NA16FL0406-01

Fisher WS, Gauthier JD, W'instead JT (1992) Infection intensity of Perkinsus marinus disease in Crassotrea virginica (Gmelin, 1791) from the Gulf of Mexico maintained under different laboratory conditions. J Shellfish Res 11:363-369

Galtsoff PS (1964) The American oyster: Crassostrea virginica (Gmelin). Fishery Bull Fish Wildl Serv US 64:1-480

La Peyre JF (1993) Studies on the oyster pathogen Perkinsus marinus (Apicomplexa): interactions with host defenses of C. virginica and C gigas, and in vitro propagation. PhD dissertation, The College of William \& Mary, Williamsburg, p 110-135

La Peyre JF, Chu, FLE (1994) A simple procedure for the isolation of Perkinsus marinus merozoites, a pathogen of the eastern oyster, Crassostrea virginica. Bull Eur Assoc Fish Pathol 14:101-103

Lucas A, Beninger PG (1985) The use of physiological condition index in marine bivalve aquaculture. Aquaculture 44: $187-200$

Mackin JG (1951) Histopathology of infection of Crassostrea virginica (Gmelin) by Dermocystidium marinum Mackin, Owen and Collier. Bull Mar Sci Gulf Caribb 1:72-87

Mackin JG (1956) Dermocystidium marinum and other microorganisms in Louisiana. Proc Natl Shellfish Assoc 46: $116-133$

Mackin JG (1962) Oyster disease caused by Dermocystidium marinum and other microorganisms in Louisiana. Publ Inst Mar Sci Univ Texas 7:132-229

Newell RI (1985) Phystological effects of the MSX parasite Haplosporidium nelsoni: (Haskin; Stanber and Mackin) on the American oyster Crassostrea virginica (Gmelin). J Shellfish Res 5:91-95

Paynter KT, Burreson EM (1991) Effects of Perkinsus marinus infection in the eastern oyster, Crassostrea virginica: II.
Disease development and impact on the growth rate at different salinities. J Shellfish Res 10:425-431

Perkins FO (1966) Life history studies of Dermocystidium marinum, an oyster pathogen. Dissertation, Florida State University

Perkins FO (1988). Structure of protistan parasites found in bivalve molluscs. Am Fish Soc Spec Publ 18:93-111

Perkins FO (1994) Life cycle studies of Perkinsus marinusHost specificity. Final Report. NOAA NMFS, Oyster Disease Research Program. Award No. NA26FL0380-01

Powell EN, Gauthier JD, Wilson EA, Nelson A, Fay RA, Brooks JM (1992) Oyster disease and climatic changes in Perkinsus marinus parasitism in oysters (Crassostrea virginical controlled by climatic cycles in the Gulf of Mexico? PSZN I: Mar Ecol 13:243-270

Quick JA, Mackin JG (1971) Oyster parasitism by Labrynthomyxa marina in Florida. Fl Dep Nat Resources Mar Lab, Prof Pap Ser 13:1-55

Ragone-Calvo LM, Burreson EM (1994) Characterization of overwintering infections of Perkinsus marinus (Apicomplexa) in Chesapeake Bay oysters. J Shellfish Res 13: $123-130$

Ragone-Calvo LM, Burreson EM (1995) Status of the major oyster diseases in Virginia - 1994: a summary of the annual monitoring program. Marine Resource Report 95-5. Virginia Institute of Marine Science, The College of William and Mary, Gloucester Point, VA.

Ray SM (1952) A culture technique for the diagnosis of infections with Dermocystidium marinum Mackin, Owen and Collier in oysters. Science 116:360-361

Ray SM (1954) Biological studies of Dermocystidium marinum, a fungus parasite of oysters. Rice Institute pamphlet $114 \mathrm{pp}$ (monograph in Biological Special Series Issue)

Ray SM (1966) A review of the culture method for detecting Dermocystidium marinum with suggested modifications and precautions. Proc Nat Shellfish Assoc 54:55-80

Scott GI, Middaugh DP, Simmons TI (1985) Interactions of chlorine-produced oxidants (CPO) and salinity in affecting lethal and sublethal effects in the eastern or American oyster, Crassostrea virginica (Gmelin), infected with the protistan parasite, Perkinsus marinus. In: Vernberg FF. Thurgerg FP, Calabrese A, Vernberg WB (eds) Marine pollution and physiology: recent advances. University of South Carolina Press, Columbia, p 351-376

Soniat TM (1985) Changes in levels of infection of oysters infected by Perkinsus marinus, with special reference to the interaction of temperature and salinity upon parasitism. Northeast Gulf Sci 7:171-174

Soniat TM, Gauthier JD (1989) The prevalence and intensity of Perkinsus marinus from the mid northern Gulf of Mexico with comments on the relationship of the oyster parasite to temperature and salinity. Tul Stud Zool Bot 27:21-27

Valiulis GA (1973) Comparison of the resistance to Labyrinthomyxa marina with resistance to Minchinia nelsoni in Crassostrea virginica. PhD dissertation, Rutgers, The State University of New Jersey, New Brunswick

Volety AK (1995) A study of the histozoic oyster parasite, Perkinsus marinus: I. Disease processes in American oysters (Crassostrea virginica); II. Biochemistry of Perkinsus marinus. PhD dissertation, The College of William and Mary, Williamsburg

Volety AK, Chu FLE (1994) Comparison of infectivity and pathogenecity of two lifestages, meront (trophozoite) and prezoosporangiae stages of the oyster pathogen Perkinsus marinus in Eastern oysters, Crassostrea virginica (Gmelin 1791). J Shellfish Res 13:521.-527 